\title{
Relato de caso: Celiotomia em jabuti-piranga (Chelonoidis carbonariapara) para remoção de ovos retidos em oviduto
}

\section{Celiotomy in jabuti-piranga (Chelonoidis carbonaria) to remove eggs retained in oviduct: Case report}

DOI: $10.53499 /$ sfjeasv1n4-004

Received in: August 1st, 2021

Accepted in: September 30th, 2021

\author{
Victória Galheriano Maia \\ Graduanda em Medicina Veterinária pela Universidade Paulista (UNIP). \\ Hospital Veterinário Fullpet \\ Rua Jamil João Zarif, 888 - Taboão - Guarulhos SP, Brasil \\ E-mail: victoriagalheriano@gmail.com \\ Daniele Mesquita Grangeiro \\ Graduanda em Medicina Veterinária pela Universidade Cruzeiro do Sul \\ Hospital Veterinário Fullpet \\ Rua Jamil João Zarif, 888 - Taboão - Guarulhos SP, Brasil \\ E-mail: danielinha.mesquita@hotmail.com

\section{Marcos Levi Santos} \\ Graduando em Medicina Veterinária (Universidade Guarulhos) \\ Hospital Veterinário Fullpet. \\ Rua Jamil João Zarif, 888 - Taboão - Guarulhos/SP, Brasil. \\ E-mail: mlevisantos@gmail.com

\section{Danilo Cabral} \\ Medico Veterinário (UNIP) \\ Mestrado em Patologia Ambiental e Experimental (UNIP) \\ Hospital Veterinário Fullpet \\ Rua Jamil João Zarif, 888 - Taboão - Guarulhos SP, Brasil \\ E-mail: danilocabral11@gmail.com
}

\section{Everton José Buzzo}

Doutor em Ciências pela Faculdade de Economia, Administração e Contabilidade de Ribeirão Preto - USP

Centro Universitário Estácio de Ribeirão Preto

Endereço: Rua Abrahão Issa Halach, 980 - Ribeirânia, Ribeirão Preto - SP, Brasil

E-mail: everton.buzzo@estacio.br

\section{Alison Chagas Rodrigues Silva}

Medico Veterinário (Universidade Guarulhos)

Hospital Veterinário Fullpet

Rua Jamil João Zarif, 888 - Taboão - Guarulhos SP, Brasil

E-mail: alisonchagasmv@gmail.com 


\title{
Polliana Pimentel \\ Médica Veterinária (Universidade Guarulhos) \\ Hospital Veterinário Fullpet \\ Rua Jamil João Zarif, 888 - Taboão - Guarulhos SP, Brasil \\ E-mail: polliana.89@icloud.com
}

Paulo Usignolo Carnauba Vicente

Medico Veterinário (Anhembi Morumbi) e Biólogo (Universidade Guarulhos)

Pós-Graduado em Clínica Medica e Cirurgica de Pequenos Animais (UNICASTELO)

Hospital Veterinário Fullpet

Rua Jamil João Zarif, 888 - Taboão - Guarulhos SP, Brasil

E-mail: paulo_usignolo@yahoo.com.br

\section{RESUMO}

Os jabutis (Chelonoidis carbonaria) são quelônios de hábitos terrestres, pertencentes à família Testudinidae, sendo provavelmente o quelônio que mais tem sido mantido em cativeiro como animal de estimação. Dentre as principais patologias reprodutivas encontradas nesta espécie podemos destacar a distocia, que raramente tem sido relatada em répteis selvagens. A retenção de ovos é uma enfermidade em que os sinais clínicos não são específicos e debilitam o animal severamente. Os processos patológicos que envolvem a retenção de ovos relacionam-se a diversos fatores. O presente trabalho teve por objetivo relatar um caso clinico cirúrgico de retenção de ovos em Chelonoidis carbonaria, diagnosticado através de exame físico, anamnese e o uso de estudo radiográfico. O tratamento clinico convencional sugerido não foi eficiente. Sendo assim, o animal foi encaminhado ao tratamento cirúrgico por celiotomia e remoção dos ovos retidos. Todos os ovos foram retirados e o animal foi acompanhado clinicamente por 60 dias, sem complicações durante esse período.

Palavra-chave: Jabuti-piranga, quelônios, celiotomia, retenção de ovos.

\begin{abstract}
Tortoises (Chelonoidis carbonaria) are terrestrial chelonians, belonging to the Testudinidae family, being probably the chelonian that has been kept in captivity as a pet. Among the main reproductive problems found in this species we can highlight dystocia, which has rarely been reported in wild reptiles. And retention of eggs is a disease in which clinical signs are not specific and severely debilitate the animal. The pathological processes that involve the retention of eggs are related to several factors. This study aimed to report a surgical clinical case of egg retention in Chelonoidis carbonaria, diagnosed through physical examination, anamnesis and the use of radiographic studies. The conventional clinical treatment suggested was not efficient. Thus, the animal was sent to surgical treatment by celiotomy and removal of retained eggs. All eggs were removed and the animal was clinically followed for 60 days, without complications during this period.
\end{abstract}

Keyword: Jabuti-piranga, quaoniums, celiotomy, egg retention, reptiles 


\section{INTRODUCTION}

The Chelonoidis carbonaria, popularly known as Jabuti-piranga, are terrestrial reptiles belonging to the order Quelonia and family Testudinidae. These animals are widely distributed in South America, including Brazil (ERNST \& BARBOUR, 1989). Due to the widespread illegal trade of the species, it is considered the Testudine with the highest prevalence of captive breeding in the country (MATIAS, et.al., 2006).

Dystocia is difficulties that the female presents during the reproductive process, culminating in egg retention, which can cause physiological dyspleus and lead to death. This condition affects approximately $10 \%$ of the reptilian population per year that is kept in captivity (MADER, 1996).

Inadequate management stands out as the main cause of dystocia in reptilians, covering erroneous feeding, an inappropriate place for making inappropriate nests and temperature and soil. However, pathological disorders can also lead to egg retention, especially broken shells, eggs with size beyond normal, hypercalcification, pelvic canal obstruction, muscle atony and endocrine dysfunction (FOWLER, et al., 2001; MATIAS, et al., 2006).

Hormonal stimulation through oxytocin administration should be the first approach to be performed in dystocia. If the treatment is not effective, the animal should be submitted to the celiotomy procedure for the removal of retained eggs (MATIAS, et al., 2006).

The present work aims to report the case of a 30-year-old jabuti-piranga who underwent the celiotomy procedure. The procedure for opening the cellomatic cavity is little described in the literature, making it necessary to elucidate this surgical approach, bearing in mind that clinical treatment is not always effective.

\section{CASE REPORT}

The animal was admitted to the FullPet veterinary hospital on April 7, 2021. Responsible reported as main complaint that the lonon iumum was less active, marking changes in behavioral characteristics. The veterinarian responsible for the oviposture of two eggs was described and, when addressing its reproductive history, it was clarified that this would be the first oviposition, without recurrence of previous or pre-existing diseases. 
The maintenance of the animal was done in a backyard with exposure of light and natural heat, with no control over these factors. The food was based on various vegetables, vegetables and fruits.

The animal was apathetic to perform the physical examination, however, all other vital parameters were within the normal range for the species. In view of the clinical history, it was referred for radiography in dorsoventral projection, in order to visualize the cellomatic cavity. For the radiographic study, the animal was kept in ventral decubitus through physical containment without many complications. From this, eleven welldelimited radiopaque structures were evidenced, characterizing the presence of retained eggs (IMAGE 01A).

Taking into account the clinical picture of the animal, it was kept hospitalized for better monitoring. The clinical treatment initially instituted was hormonal stimulation through the administration of two doses of oxytocin 2 IU/IM, with an interval of two hours between them. Calcium replacement was also performed at a dose of $0.3 \mathrm{ml} / \mathrm{IV}$ occiptal sinus. It was kept at rest in warm water.

After treatment, the animal expelled an egg (IMAGE 01B), keeping ten retained in the oviduct. She was kept under observation for possible oviposture of the other. Hormonal treatment with oxytocin was lasted for 4 days in an attempt at a noninvasive approach. After this period, valuing the animal's health, celiotomy procedure was chosen for egg removal.
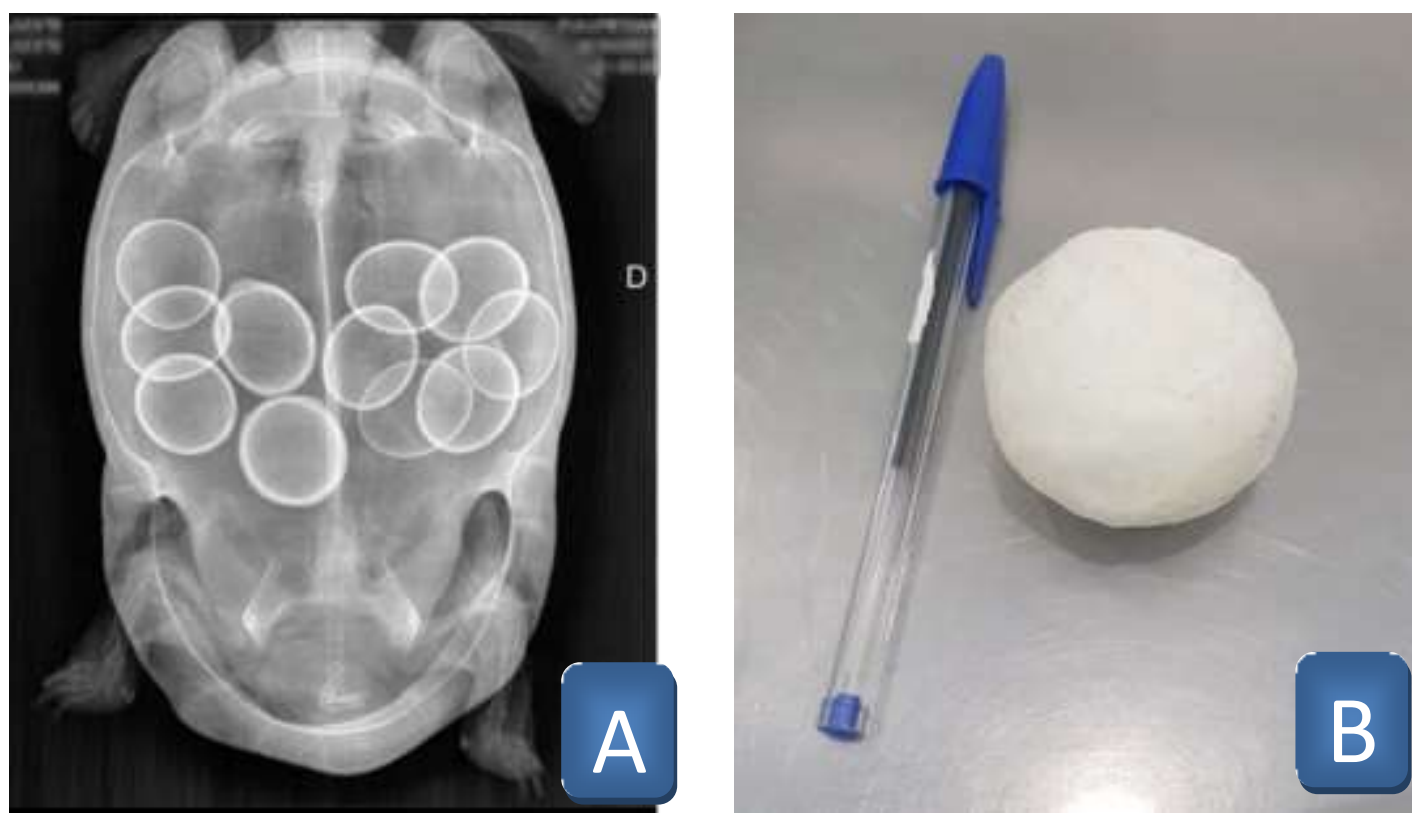

IMAGE 01A - Dorsoventral radiograph showing 11 ovoid structures with a circumscribed radiopaque characteristic. IMAGE 01B - only egg that hatched during clinical treatment with handling and oxytocin. 
To perform the surgical procedure, ketamine $5 \mathrm{mg} / \mathrm{Kg} / \mathrm{IV}$ was administered as preanesthetic medication. The agent used for anesthetic induction was propofol 0.5 $\mathrm{mg} / \mathrm{kg} / \mathrm{in}$ bolus. The maintenance of the anesthetic plan was performed by the inhaled agent isoflurane at $2 \%$ (CUBAS, et al., 2014).

After the anesthetic protocol, the surgical procedure was initiated. An oscillatory saw was used to open the plastron. It is an instrument little used in the practice of the veterinarian, however, prevents cuts or perforations of the vital organs of the animal. After opening the bone structure, an incision was made in the cellomatic membrane, and the oviduct was started (IMAGE 02A). After localization, it was exposed and the opening was carried out for egg removal (IMAGE 02B).
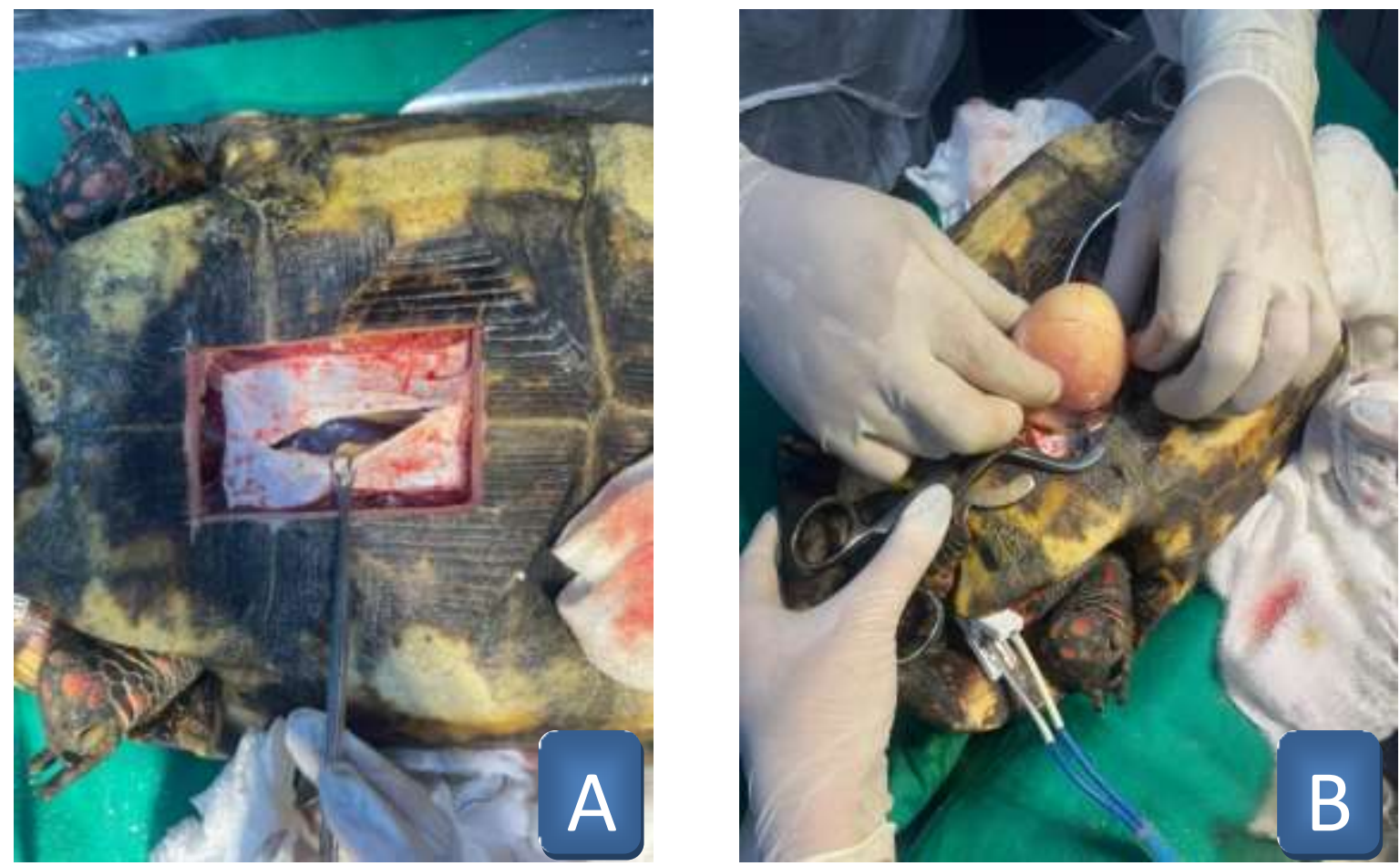

IMAGE 02A - After sawing the plastron (ventral plate), note the coelomatic membrane. IMAGE 02B Evidencing and exposing the oviduct.

The retained eggs were removed one by one and counted later (IMAGE 03A). Then, the oviduct was sutured with polydioxanone 0 monofilament thread. The closing process was started without signs of bleeding or other complications.

For the closure of the cellomatic membrane, polyglycolic acid 2-0 multifilament suture was used, to avoid the use of non-absorbable wires and foreign body maintenance inside the animal throughout its life. Subsequently, the plastron was recolated at its proper anatomical site. Four orthopedic stainless steel plates with four screws each were used to 
level and fix the plastron (IMAGE 03 A). Next, the use of resin was used to close the surgical area (IMAGE 03B).
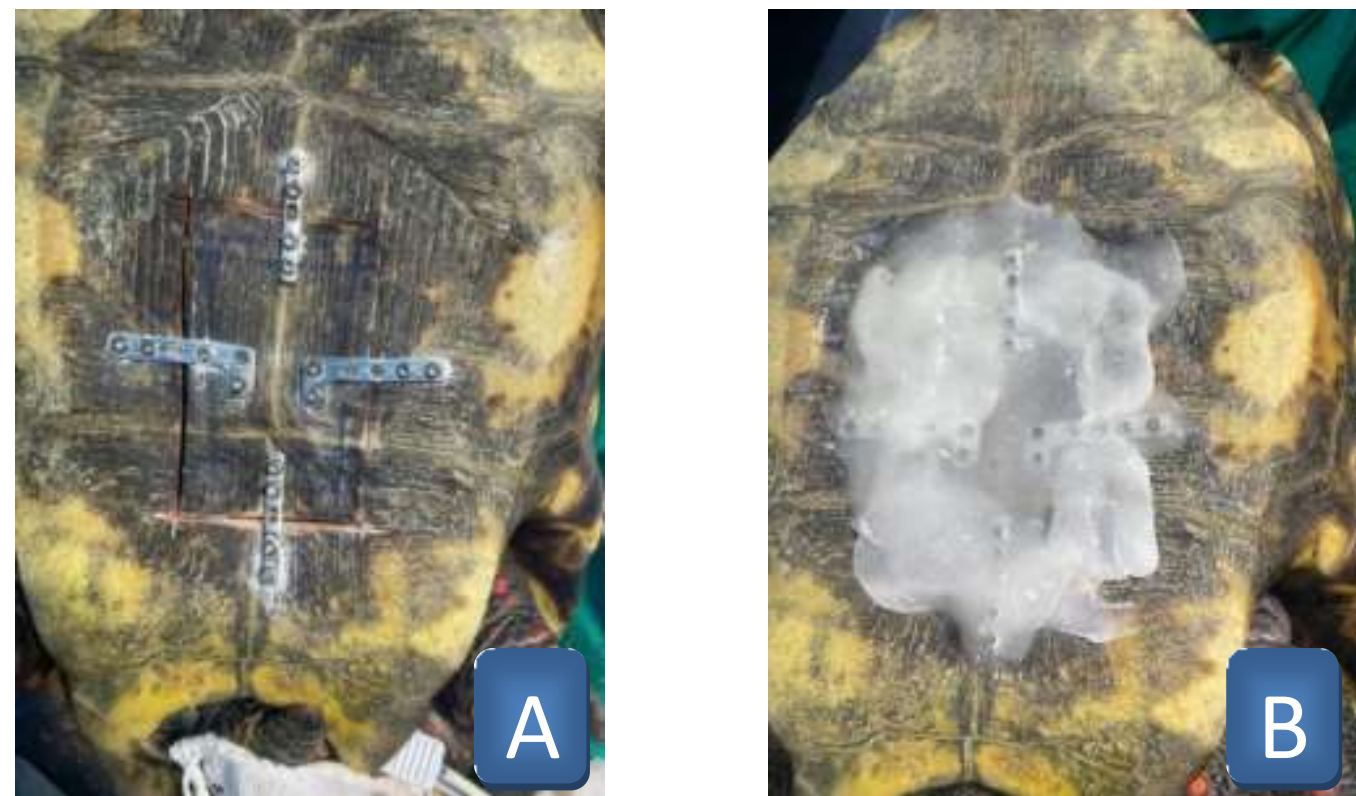

IMAGE 03A- - Fixation and alignment of surgical orthopedic places, for fixation with surgical screws. IMAGE 03B - Closure of the plasto area with dental resin.

\section{CONCLUSION/DISCUSSION}

As already highlighted by Mader (1996), the scientific literature on dystocia is limited, with predominance of case reports focused on treatment. Therefore, much information is based on authors' experience, personal communication with colleagues, and limited scientific literature.

In the search for theoretical references in the various scientific indexers to carry out the work, it was evident the difficulty in finding research and articles on the subject. However, the books were an excellent source of information that contributed to the theoretical enrichment of the study.

Currently, the number of people seeking tortoises for pet animals has been growing. However, they often do not have the knowledge about the care these animals need in captivity. Having said that, the role of the veterinarian is, whenever possible, to guide the person responsible about the essential care that the animal should have, seeking to prevent future complications.

The surgical procedure of celiotomy is extremely invasive and complex to be performed. Therefore, noninvasive treatment with oxytocin should be the first conduct of the professional (MADER, 1996). In the case presented, hormonal stimulation was not 
efficient and the surgical procedure was the only solution to ensure the health and wellbeing of the animal.

Due to the facts analyzed, the primary function of the veterinarian is to prevent this type of complication as much as possible through guidance. However, you should be prepared to come across this situation in the routine and know how to act in the best possible way. 


\section{REFERENCE}

CUBAS, Z.S.; SILVA, J.C.R.; CARTÃO-DIAS, J.S. Tratado de Animais Selvagens. São Paulo: Roca, 2492p., 2014.

ERNST, C.H.; BARBOUR, R.W. Turtles of the world. Washington DC.: Smithsonian Institution, 313p., 1989.

MADER, D.R. Reptile medicine and surgery. Philadelphia: Saunders, 512p., 1996.

MATIAS, C. A. R. et al., Aspectos fisiopatológicos da retenção de ovos em Jabuti piranga (Geochelone carbonaria Spix, 1824). Cienc. Rural, Santa Maria, v. 36, n. 5, p. 1494-1500, Oct. 2006. Disponível em <http://www.scielo.br/scielo.php?script=sci_arttext\&pid=S010384782006000500023\&1 ng=en\&nrm=iso>. Acesso em: 17 de abr. de 2021.

FOWLER, M. E.; CUBAS, Z. S., Biology, medicine, and surgery of south american wild animals. Estados Unidos: Iowa State University Press, 548p., 2001. 